\title{
Pengaruh Disiplin Kerja Karyawan Terhadap Produktifitas Karyawan PT. Sahabat Unggul Internasional
}

\author{
Ade Onny Siagian \\ Universitas Bina Sarana Informatika, Jakarta, Indonesia \\ Email: ade.aoy@bsi.ac.id
}

(Diterima: Okt 2020; Direvisi: Nov 2020; Dipublikasikan: Jan 2021)

\begin{abstract}
ABSTRAK
Tujuan penelitian ini adalah untuk memperoleh data dan informasi dari perusahaan yang mengenai hal-hal yang berhubungan dengan permasalahan khususnya untuk mengetahui pengaruh disiplin kerja karyawan terhadap produktivitas karyawan PT. Sahabat Unggul International. Penelitian ini dilakukan dengan menggunakan jenis penelitian deskriptif development dengan metode deskriptif survei mengenai pengaruh disiplin kerja karyawan terhadap produktivitas karyawan PT. Sahabat Unggul International. Data yang digunakan merupakan data kualitatif yaitu data hasil jawaban kuesioner Variabel X dan Variabel Y dengan total pertanyaan 24 butir pertanyaan. Data tersebut dianalisis dengan mengunakan metode statistik berupa analisis regresi, koefisien determinasi, dan uji hipotesis koefisien regresi. Hasil analisis regersi diperoleh persamaan $Y=8,570+0,804 \mathrm{X}$ dari persamaan tersebut dapat diartikan bahwa jika tidak ada disiplin kerja maka produktivitas nilainya 8,570 , sedangkan pada setiap peningkatan pelatihan disiplin kerja sebesar satu, jika hasil t hitung sebesar 14,11636 dan angka tersebut lebih besar dari pada t tabel dengan signifikasi 5\% dan df-2 yaitu 1,65895. Karena t hitung $(14,11636>1,65895) \mathrm{t}$ tabel maka Ho ditolak. Jadi dapat disimpulkan bahwa disiplin kerja berpengaruh terhadap produktivitas.
\end{abstract}

\section{Kata Kunci: Disiplin Kerja, Produktifitas, Karyawan}




\section{PENDAHULUAN}

Masyarakat Ekonomi Asean (MEA) 2015 merupakan realisasi pasar bebas di Asia Tenggara yang telah dilakukan secara bertahap mulai KTT ASEAN di Singapura pada tahun 1992. Tujuan dibentuknya Masyarakat Ekonomi ASEAN (MEA) untuk meningkatkan stabilitas perekonomian di kawasan ASEAN, serta diharapkan mampu mengatasi masalah-masalah di bidang ekonomi antar negara ASEAN. Konsekuensi atas kesepakatan MEA tersebut berupa aliran bebas barang bagi negara-negara ASEAN, dampak arus bebas jasa, dampak arus bebas investasi, dampak arus tenaga kerja terampil, dan dampak arus bebas modal. Oleh karena itu dari sisi pemerintah juga dilakukan strategi dan langkah-langkah agar Indonesia siap dan dapat memanfaatkan momentum MEA. (http://www.bppk. kemenkeu.go.id).

Dalam mencari sumber daya manusia (karyawan) yang memiliki kompetensi bukan hanya dilihat dari penampilan, latar belakang pendidikan, atau pengalaman kerja seseorang di sepanjang hidupnya, tetapi kita perlu juga melihat dan menilai sumber daya yang mempunyai tingkat disiplin kerja yang tinggi. Karena disiplin merupakan suatu keadaan tertentu dimana orang - orang yang tergabung dalam organisasi dan tunduk terhadap peraturan - peraturan yang ada. Maka disiplin kerja harus ditegakkan dalam suatu organisasi karena tanpa dukungan disiplin kerja yang baik maka organisasi akan sulit dalam mewujudkan tujuannya. Jadi dapat dikatakan bahwa disiplin kerja merupakan kunci keberhasilan suatu organisasi dalam mencapai tujuan yang ditentukan.

PT. Sahabat Unggul International yang beralamat di JL. Jendral Achmad Yani No.28 kota Bogor, Perusahaan ini bergerak di bidang tekstile garmen, kegiatan operasi yang dilakukan perusahaan adalah aktivitas pengolahan bahan mentah berupa tekstil gulungan (100\% dari pemesan) menjadi barang jadi yang berupa baju siap pakai untuk pria, wanita, dan anak-anak dengan tujuan di ekspor kembali ke negara pemberi pesanan.

Permasalahan yang timbul di perusahaan ini kurangnya kedisiplinan karyawan, tingkat ketidakhadiran dapat dilihat dari data ketidakhadiran, berikut tingkat ketidakhadiran karyawan pada PT. Sahabat Unggul International.

Tabel 1. Data Tingkat Ketidakhadiran Karyawan Pada PT. Sahabat Unggul International Periode 2019.

\begin{tabular}{|c|c|c|c|c|c|c|c|c|c|}
\hline \multirow[b]{2}{*}{ No } & \multirow[b]{2}{*}{ Bulan } & \multirow{2}{*}{$\begin{array}{c}\text { Jumlah } \\
\text { rata - rata } \\
\text { karyawan }\end{array}$} & \multirow{2}{*}{$\begin{array}{l}\text { Hari } \\
\text { Kerja }\end{array}$} & \multicolumn{3}{|c|}{ Jumlah } & \multirow{2}{*}{$\begin{array}{c}\text { Total } \\
\text { Ketidakhadiran }\end{array}$} & \multicolumn{2}{|c|}{ Presentase } \\
\hline & & & & Sakit & Ijin & Alfa & & Std & Realisasi \\
\hline 1 & Januari & 1678 & 26 & 372 & 75 & 515 & 962 & $2 \%$ & $2,21 \%$ \\
\hline 2 & Februari & 1678 & 25 & 426 & 77 & 494 & 997 & $2 \%$ & $2,38 \%$ \\
\hline 3 & Maret & 1678 & 27 & 473 & 105 & 605 & 1183 & $2 \%$ & $2,61 \%$ \\
\hline 4 & April & 1678 & 26 & 451 & 120 & 594 & 1165 & $2 \%$ & $2,67 \%$ \\
\hline 5 & Mei & 1678 & 26 & 186 & 105 & 258 & 549 & $2 \%$ & $1,26 \%$ \\
\hline 6 & Juni & 1678 & 26 & 114 & 43 & 145 & 302 & $2 \%$ & $0,69 \%$ \\
\hline 7 & Juli & 1678 & 26 & 89 & 32 & 152 & 273 & $2 \%$ & $0,63 \%$ \\
\hline 8 & Agustus & 1678 & 27 & 177 & 51 & 234 & 462 & $2 \%$ & $1,02 \%$ \\
\hline 9 & September & 1678 & 26 & 141 & 118 & 329 & 588 & $2 \%$ & $1,35 \%$ \\
\hline
\end{tabular}




\begin{tabular}{|l|c|c|c|c|c|c|c|c|c|}
\hline 10 & Oktober & 1678 & 26 & 130 & 81 & 361 & 572 & $2 \%$ & $1,31 \%$ \\
\hline 11 & November & 1678 & 26 & 193 & 57 & 358 & 608 & $2 \%$ & $1,39 \%$ \\
\hline 12 & Desember & 1678 & 26 & 186 & 85 & 373 & 644 & $2 \%$ & $1,48 \%$ \\
\hline
\end{tabular}

(Sumber: PT. Sahabat Unggul International 2019)

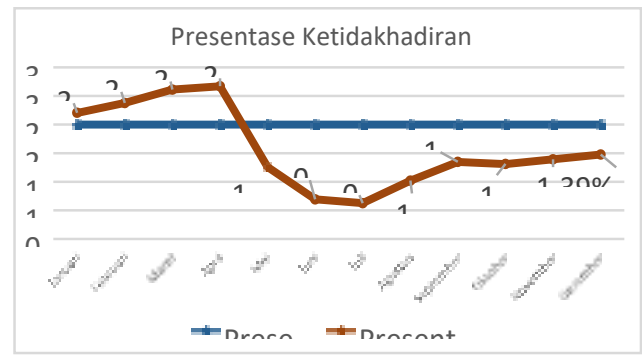

Gambar 1. Presentase Ketidakhadiran (Sumber: PT. Sahabat Unggul International 2019)
Berdasarkan data diatas, bulan januari sampai bulan maret ketidakhadiran cukup tinggi, namun di bulan April sampai bulan Juli mengalami penurunan, dibulan Agustus sampai Desember mengalami kenaikan kembali ketidakhadiran, ketidakhadiran tertinggi terdapat pada bulan Maret dan April yaitu sebesar 1183 dan 1165 orang.

Tabel 2. Data Tingkat Hasil Produksi Pada PT. Sahabat Unggul International Periode 2019.

\begin{tabular}{|c|c|c|c|c|c|c|c|}
\hline \multirow{2}{*}{ No } & \multirow{2}{*}{ Bulan } & \multirow{2}{*}{$\begin{array}{c}\text { Target } \\
\text { Produksi }\end{array}$} & \multicolumn{2}{|c|}{ Produksi } & \multirow{2}{*}{ Total } & \multicolumn{2}{|c|}{ Presentase } \\
\hline & & & FOB & CMT & & Target & Realisasi \\
\hline 1 & Januari & 100.000 & 131.807 & 941 & 132.748 & $100 \%$ & $133 \%$ \\
\hline 2 & Februari & 100.000 & 124.738 & 552 & 125.290 & $100 \%$ & $125 \%$ \\
\hline 3 & Maret & 100.000 & 107.435 & 410 & 107.845 & $100 \%$ & $108 \%$ \\
\hline 4 & April & 100.000 & 119.553 & 805 & 120.358 & $100 \%$ & $120 \%$ \\
\hline 5 & Mei & 100.000 & 81.418 & 1.346 & 82.764 & $100 \%$ & $83 \%$ \\
\hline 6 & Juni & 100.000 & 58.018 & 20.911 & 78.929 & $100 \%$ & $79 \%$ \\
\hline 7 & Juli & 100.000 & 25.585 & 4.135 & 29.720 & $100 \%$ & $30 \%$ \\
\hline 8 & Agustus & 100.000 & 44.072 & 8.833 & 52.905 & $100 \%$ & $53 \%$ \\
\hline 9 & September & 100.000 & 35.460 & 12.739 & 48.199 & $100 \%$ & $48 \%$ \\
\hline 10 & Oktober & 100.000 & 27.863 & 33.169 & 61.032 & $100 \%$ & $61 \%$ \\
\hline 11 & November & 100.000 & 44.284 & 16.330 & 60.614 & $100 \%$ & $61 \%$ \\
\hline 12 & Desember & 100.000 & 40.334 & 34.400 & 74.734 & $100 \%$ & $75 \%$ \\
\hline & Total & & 840.567 & 134.571 & 975.138 & $100 \%$ & $81 \%$ \\
\hline
\end{tabular}

(Sumber: PT. Sahabat Unggul International 2019)

Berdasarkan data di atas dapat dilihat bahwa hasil produksi pada bulan Januari sampai dengan bulan April memenuhi target. Kemudian pada bulan Mei sampai dengan bulan Desember hasil produksi mengalami penurunan. Hasil produksi mengalami penurunan yang sangat drastis terjadi pada bulan Juli sebasar 29.720 unit ini jauh dari standar produksi sebesar 100.000 unit. Berdasarkan data - data tersebut dapat disimpulkan betapa pentingnya kedisiplinan karyawan bagi suatu perusahaan dalam rangka meningkatkan produktivitas kerja karyawan. Masalah disiplin kerja harus benar - benar diperhatikan karena apabila seseorang karyawan pada suatu perusahaan tidak mempunyai disiplin kerja yang tinggi maka tujuan dan produktivitas kerja karyawan akan sulit tercapai. Bagaimana tingkat disiplin, tingkat produktivitas kerja dan apakah disiplin kerja berpengaruh pada 
produktivitas karyawan PT Sahabat Unggul International. Penelitian ini dimaksudkan untuk memperoleh data dan informasi tentang disiplin dan produktivitas kerja karyawan pada PT. Sahabat Unggul International sebagai bahan dalam penyusunan skripsi. Penelitian ini juga dimaksudkan sebagai upaya untuk menerapkan dan mengembangkan ilmu yang telah dimiliki penulis agar dapat memperoleh solusi terbaik dalam memecahkan masalah yang ada dalam perusahaan.

\section{TINJAUAN PUSTAKA}

\section{Manajemen Sumber Daya Manusia}

a. Pengertian Manajemen Sumber Daya Manusia

Manajemen sumber daya manusia (MSDM) menjadi bagian dari manajemen yang fokus pada peranan pengaturan manusia dalam mewujudkan tujuan organisasi atau perusahaan. Manusia selalu berperan aktif dalam dominan dalam setiap kegiatan organisasi karena manusia menjadi perencana, pelaku dan penentu terwujudnya tujuan organisasi. Adapun beberapa definisi manajemen sumber daya manusia yaitu sebagai berikut:

1) "Human resource management is process of acquiring and compensating employees, and of attending to their laor relationship, health and safety, and fairness concerns". (Dessler, 2011:30).

2) "Human resource management is activity designed to provide for coordinate the human resources of organization". (Byars, 1984:3)

3) "Management as the process of planning, organizing, directing, and contolling the activities of employees in combination with other organizational resources to accomplish stated organizational goals".(Steers, 1985:29)

4) "Manajemen sumber daya manusia adalah penarikan, seleksi, pengembangan, pemeliharaan, dan penggunaan sumber daya manusia untuk mencapai titik tujuan-tujuan individu maupun organisasi". (T. Hani Handoko, 2010:4)

5) "Manajemen sumber daya manusia yakni ilmu dan seni mengatur hubungan dan peranan tenaga kerja agar efektif dan efisien membantu terwujudnya tujuan perusahaan, karyawan, dan masyarakat".(Hasibuan, 2012:10)

6) "Manajemen sumber daya manusia (human resources management) adalah pendayagunaan, pengembangan, penilaian, pemberian balas jasa, dan pengelolaan individu anggota organisasi atau kelompokpekerja".

(Simamora, 2006:3)

7) "Manajemen sumber daya manusia (MSDM) adalah pemanfaatan sejumlah individu untuk mencapai tujuan tujuan organisasi". 
(Mondy, 2008:4) "Manajemen sumber daya manusia dapat didefinisikan pula sebagai suatu pengelolaan dan pendayagunaan sumber daya yang ada pada individu (pegawai)". (A.A Anwar Prabu Mangkunegara, 2007:2)

Dari seluruh definisi beberapa ahli tersebut, maka kita dapat membuat kesimpulan tentang Manajemen sumber daya manusia, yaitu sebuah ilmu serta seni dalam kegiatan perencanaan, pengorganisasian, pengarahan, pengawasan, pengembangan, pengelolaan, penilaian, pemberian balas jasa, dan pendayagunaan sumber daya manusia yang ada, serta mengatur hubungan dan peranan tenaga kerja agar efektif dan efisien membantu terwujudnya tujuan individu masyarakat maupun organisasi.

b. Tujuan Manajemen Sumber Daya Manusia

Menurut Edy Sutrisno (2014:7), tiap organisasi, termasuk perusahaan, menetapkan tujuan - tujuan tertentu yang ingin mereka capai dalam memanajemani setiap sumber dayanya termasuk sumber daya manusia. Tujuan MSDM secara tepat sangatlah sulit untuk dirumuskan karena sifatnya bervariasi dan tergantung pada penahapan perkembangan yang terjadi pada masing - masing organisasi.

"Menurut Sihotang (2007:13), tujuan manajemen sumber daya manusia adalah: tujuan social kemasyarakatan, tujuan organisasional, tujuan fungsional, tujuan pribadi para pekerja".

Menurut Veithzal Rivai Zainal (2015:12), tujuan akhir yang ingin dicapai manajemen SDM pada dasarnya:

1. Peningkatan efisiensi

2. Peningkatan efektivitas

3. Rendahnya tingkat perpindahan pegawai

4. Rendahnya tingkat absensi

5. Tingginya kepuasan kerja karyawan

6. Tingginya kualitas pelayanan

7. Rendahnya komplain dari pelanggan

8. Meningkatnya bisnis perusahaan

\section{Disiplin}

\section{a. Pengertian Disiplin}

Disiplin berasal dari Bahasa inggris "disciple" yang berarti "pengikut" atau "penganut", "pengejaran", "pelatihan" dan sebagainya. Adapun definisi disiplin kerja menurut para ahli: 1) "Discipline is any action designed to correct associate deviation from organizational rules, procedures, policies, and norms".(Newman, 1998:261)

2) "Disiplin adalah sikap hormat terhadap peraturan dan ketetapan perusahaan, yang ada dalam diri karyawan, yang menyebabkan ia dapat menyesuaikan diri dengan sukarela pada peraturan dan ketetetapan perusahaan".(Edy Sutrisno, 


\section{4:87)}

3) "Disiplin adalah kegiatan manajemen untuk menjalankan standar standar organisasional". (T. Hani Handoko, 2010:208)

4) Disiplin adalah kesadaran dan kesediaan seseorang menaati semua peraturan perusahaan dan norma norma sosial yang berlaku. Kedisiplinan harus di tegakan dalam suatu organisasi tanpa dukungan disiplin karyawaan yang baik, sulit bagi perusahaan untuk mewujudkan tujuannya. Jadi, kedisiplinan adalah kunci keberhasilan suatu perusahaan dalam mencapai tujuannnya. (Hasibuan, 2012:193)

5) Disiplin adalah sebagai sikap mental yang tercermin dalam perbuatan atau tingkah laku perorangan, kelompok atau masyawakat berupa ketaatan (obedience) terhadap peraturan - peraturan yang ditetapkan pemerintah atau etik, norma dan kaidah yang berlaku dalam masyarakat untuk tujuan tertentu. (Sinungan, 2009:145)

6) "Kedisiplinan adalah kesadaran dan kesediaan seseorang dalam menaati semua peraturan perusahaan dan norma - norma yang berlaku".

(Hasibuan, 2012:193)

7) "Disiplin adalah sebuah proses yang digunakan untuk menghadapi permasalahan kinerja perusahaan, proses ini melibatkan manajer dalam mengidentifikasikan dan mengakumulasikan masalah - masalah kinerja kepada karyawan". (Irham Fahmi, 2016:29)

8) "Disiplin kerja dapat di artikan sebagai pelaksanaan manajemen untuk memperteguh pedoman pedoman organisasi". (A.A Anwar Prabu Mangkunegara, 2007:129)

9) "Disiplin merupakan tindakan manajemen untuk mendorong para anggota organisasi memenuhi tuntutan berbagai ketentuan tersebut".(Siagian, 2008:305)

10) Disiplin kerja adalah suatu alat yang digunakan para manajer untuk berkomunikasi dengan karyawan agar mereka bersedia untuk mengubah suatu perilaku serta sebagai upaya untuk meningkatkan kesadaran dan kesediaan seseorang menaati semua peraturan perusahaan dan norma - norma sosial yang berlaku. (Veithzal Rivai Zainal, 2015:599)

Jadi, dapat disimpulkan bahwa disiplin adalah proses kesediaan kesadaran maupun sikap hormat tehadap peraturan dan ketetapan perusahaan dalam menaati atau menjalankan standar - standar dan norma - norma perusahaan baik perorangan maupun kelompok, kedisiplinan adalah kunci keberhasilan suatu perusahaan dalam mencapai tujuannnya. 


\section{b. Indikator Disiplin}

Adapun indikator disiplin kerja menurut para ahli, diantaranya sebagai berikut:

Sutrisno

menjelaskan bahwa, disiplin kerja memiliki indikator:

1. Kehadiran

a. Para pegawai harus dating tepat waktu.

b. Pegawai harus mengisi daftar hadir.

c. Menerima kosekuensi atas ketidakhadiran.

2. Waktu kerja

a. Tepat waktu datang dan pulang dalam kerja

b. Jam istirahat tidak dihitung sebagai jam kerja.

c. Pegawai wajib menaati jam kerja dan melaksanakan tugas.

3. Peraturan berpakaian

a. Kemampuan untuk menjaga penampilan, kebersihan, kerapihan.

b. Menggunakan pakaian dinas atau PDH sesuai dengan ketentuan.

c. Disiplin pada pakaian dan atribut.

4. Peratutan melakukan pekerjaan

a. Ketelitian dalam bekerja.

b. Mengerjakan pekerjaan secara effektif dan effisien.

c. Hati - hati dalam melakukan pekerjaan.

Dari beberapa pendapat ahli tentang indikator disiplin di atas, dapat disimpulkan bahwa indikator disiplin terdiri dari : kehadiran, ketaatan pada peraturan kerja, ketaatan pada standar kerja, tingkat kewaspadaan yang tinggi, tujuan \& kemampuan, teladan pimpinan, balas jasa, keadilan, waskat, sanksi hukuman, ketegasan, dan hubungan manusia.

\section{Produktivitas Kerja}

\section{a. Pengertian Produktivitas Kerja}

Secara umum

produktivitas mengandung pengertian perbandiangan

Antara hasil yang dicapai (output) dengan keseluruhan sumber daya yang digunakan (input). Setiap perusahaan selalu berusaha agar karyawan bisa berprestasi dalam bentuk memberikan produktivitas kerja yang maksimal. Produktivitas kerja karyawan bagi suatu perusahaan sangatlah penting sebagai alat pengukur keberhasilan dalam menjalankan usaha.

Berdasarkan beberapa definisi produktivitas di atas dapat diambil kesimpulan bahwa produktivitas adalah perbandingan antara hasil akhir yang di capai (output) dengan kesuluruhan sumber daya manusia atau pengorbanan yang digunakan (input), dikatakan kurang produktif jika makin tinggi input yang diperlukan untuk mencapai penghasilan tertentu oleh karna itu produktivitas juga disebut ukuran efisiensi produktif.

b. Faktor - faktor yang mempengaruhi produktivitas kerja 
Peningkatan produktivitas kerja dapat dilihat sebagai masalah keperilakuan, tetapi juga dapat mengandung aspek aspek teknis. Untuk mengatasi hal itu perlu pemahaman yang tepat tentang faktor - faktor penentu keberhasilan meningkatkan produktivitas kerja, sebagian di antaranya berupa etos kerja yang harus dipegang teguh oleh semua karyawan dalam organisasi.

Menurut

Sugiyono (2010:213) menyebutkan, ada beberapa faktor yang mempengaruhi produktivitas suatu insane, antara lain:

a. Knowlege Sebenarnya, pengetahuan (knowledge) merupakan salah satu yang mendasar menciptakan pencapaian produktivitas. Pengetahuan lebih berorientasi pada intelegensi, daya pikir dan penguasaan ilmu, serta luas sempitnya wawasan yang dimiliki seseorang. Dengan pengetahuan yang luas dan berpendidikan tinggi, seorang pegawai diharapkan mampu melakukan pekerjaan dengan baik dan produktif.

b. Skill adalah kemampuan dan penguasaan teknis operasional mengenai bidang tertentu, yang bersifat kekaryawanan. Keterampilan diperoleh dengan belajar dan berlatih. Kerampilan berkaitan dengan kemampuan seseorang untuk melakukan atau menyelesaikan pekerjaan - pekerjaan yang bersifat teknis.

c. Abilities (kemampuan) terbentuk dari sejumlah kompetensi yang dimiliki oleh seorang pegawai. Pengetahuan dan keterampilan termasuk faktor pembentukan kemampuan. Dengan demikian, apabila seseorang mempunyai pengetahuan dan keterampilan yang tinggi, diharapkan memiliki abilities yang tinggi pula.

d. Attitude merupakan suatu kebiasaan yang terpolakan. Jika kebiasaan yang terpolakan tersebut memiliki implikasi positif dalam hubungan dengan perilaku kerja seseorang maka akan menguntungkan.

Menurut Sinungan (2009:66) menyebutkan bahwa yang dapat mempengaruhi produktivitas kerja adalah sebagai berikut:

a. Tenaga kerja, Kenaikan sumbangan tenaga kerja pada produktivitas dikarenakan adanya tenaga kerjayang lebih sehat, terdidik, dan lebih giat. Produktivitas dapat meningkat, karena hari kerja yang lebih pendek. Imbalan dan pengawas dapat mendorong karyawan lebih giat dalam mencapai prestasi. Dengan demikian jelas bahwa tenaga kerja berperan penting dalam produktivitas.

b. Seni serta ilmu manajemen, Manajemen adalah faktor 
produksi dan sumber daya ekonomi sedangkan seni adalah pengetahuan manajemen yang memberikan kemungkinan peningkatan produktivitas. Manajemen termasuk perbaikan melalui penerapan teknologi serta pemanfaatan pengetahuan yang memerlukan pendidikan dan penelitian.

c. Modal perusahaan merupakan landasan gerak suatu usaha, karena dapat menyediakan peralatan bagi manusia, yaitu membantu melakukan pekerjaan dalam meningkatkan produktivitas kerja. Fasilitas yang memadai membuat semangat kerja bertambah, sehingga secara tidak langsung produktivitas kerja dapat meningkat.

\section{c. Indikator Produktivitas}

Menurut Ambar Teguh Sulistyani dan Rosidah dalam Indah Puji Hartatik (2014:213), ada beberapa faktor yang menentukan besar kecilnya produktivitas suatu instansi antara lain:

a. Pengetauan (knowledge) merupakan salah satu yang mendasari pencapaian produktivitas. Pengetahuan lebih berorientasi pada intelegensi, daya pikir, dan penugasaan ilmu, serta luas sempitnya wawasan yang dimiliki seseorang. Dengan pengetahuan yang luas dan pendidikan yang tinggi, seorang pegawai diharapkan mampu melakukan pekerjaan dengan baik dan produktif.

b. Keterampilan (skill) adalah kemampuan dan penugasan teknis operasional mengenai bidang tertentu, yang bersifat kekaryaan. Keterampilan diperoleh melalui proses belajar dan berlatih keterampilan berkaitan dengan kemampuan seseorang untuk melakukan atau menyelesaikan pekerjaan pekerjaan yang bersifat teknis.

c. Kemampuan terbentuk dari sejumlah kompetensi yang dimiliki oleh seorang pegawai. Pengetahuan dan keterampilan, termasuk faktor pembentuk kemampuan. Dengan demikian, apabila seseorang mempunyai pengetahuan dan keterampilan yang tinggi, maka ability yang tinggi pula.

d. Sikap merupakan suatu kebiasaan yang terpolakan. Jika kebiasaan yang terpolakan tersebut memiliki implikasi positif dalam hubungannya dengan perilaku kerja seseorang maka akan menguntungkan.

\section{Kerangka Pemikiran}

Edy Sutrisno, (2009:97) menyatakan bahwa kegiatan pendisiplinan yang dilaksanakan untuk mendorong para karyawan agar mengikuti berbagai standart dan aturan, sehingga penyelewengan - penyelewengan 
dapat dicegah. Sasaran pokoknya adalah untuk mendorong disiplin diri diantara para karyawan untuk datang tepat waktu. Dengan datang tepat waktu dan melaksanakan tugas sesuai dengan tugasnya, maka diharapkan produktivitas kerja akan meningkat. Sedangkan menurut para ahli produktivitas adalah perbandingan antara hasil akhir yang di capai (output) dengan kesuluruhan sumber daya manusia atau pengorbanan yang digunakan (input), dikatakan kurang produktif jika makin tinggi input yang diperlukan untuk mencapai penghasilan tertentu oleh karna itu produktivitas juga disebut ukuran efisiensi produktif. Dengan indikator menurut Ambar Teguh Sulistyani dan Rosidah dalam Indah Puji Hartatik (2014:213) yaitu:

1. Pengetahuan

2. Keterampilan

3. Kemampuan

4. Sikap

Menurut Veithzal Rivai (2008:444) menjelaskan bahwa, indikator disiplin kerja seperti:

1. Kehadiran

2. Ketaatan pada peraturan kerja

3. Ketaatan pada standar kerja

4. Tingkat kewaspadaan tinggi Apabila diantara pegawai sudah tidak menghiraukan kedisiplinan kerja, maka dapat dipastikan produktivitas kerja akan menurun. Padahal untuk mendapatkan produktivitas kerja sangat diperlukan kedisiplinan dari para pegawai.

\section{Hipotesis Penelitian}

Berdasarkan perumusan masalah diatas maka hipotesis disusun sebagai berikut: a. Pelaksanaan disiplin kerja karyawan pada PT. Sahabat Unggul International kurang baik.

b. Tingkat produktivitas kerja karyawan pada PT. Sahabat Unggul International kurang baik.

c. Diduga adanya pengaruh yang positif dan signifikan antara disiplin terhadap produktivitas kerja karyawan pada PT. Sahabat Unggul International

\section{METODE PENELITIAN}

\section{Jenis Penelitian}

Jenis penelitian ini adalah penelitian deskriptif development dengan metode penelitian deskriptif survei, peneliti ingin mengetahui pengaruh disiplin kerja karyawan terhadap produktivitas karyawan pada PT. Sahabat Unggul International.

2. Objek, Unit Analisis, Dan Lokasi Penelitian

Objek penelitian ini menggunakan 2 variabel yaitu terdiri dari variabel $(\mathrm{x})$ disiplin sebagai variabel independen yang mempengaruhi dengan indikator yaitu kehadiran, ketaatan pada peraturan kerja, ketaatan pada standar kerja \& tingkat kewaspadaan tinggi. Produktivitas kerja sebagai variabel yang dependent (y) variabel yang dipengaruhi dengan indikator pengetahuan, keterampilan, kemampuan, dan sikap.

Penulis mengambil lokasi penelitian ini pada PT Sahabat Unggul International yang bergerak di bidang tekstile garmen dan beralamat di Jln. Jend. A. Yani. No 28.Bogor. 


\section{Jenis Data dan Sumber Data} Penelitia

Jenis data dalam penelitian ini ada dua yaitu: data kuantitatif dan data kualitatif

\section{Metode Pengumpulan Data}

Metode pengumpulan data yang digunakan penulis yaitu: Penelitian Kepustakaan (Library Research) Yaitu memperoleh data melalui berbagai sumber teoritis dari buku (Literature) yang berkaitan dengan masalah yang diteliti.

\section{HASIL PENELITIAN}

Disiplin kerja pada PT. Sahabat Unggul International diukur melalui pertanyaan - pertanyaan dalam kuisioner, hasil jawaban responden mencakup pilihan sangat setuju hingga sangat tidak setuju. Jawaban responden terhadap disiplin kerja terkait aktivitas didalam PT. Sahabat Unggul International. Berdasarkan tanggapan tersebut dilakukan analisis deskriptif guna menjelaskan disiplin kerja pada PT. Sahabat Unggul International.

1. Kehadiran

Tabel 4. Pendapat Responden Mengenai Pernyataan "Hadir Setiap Hari"

\begin{tabular}{|c|c|c|c|c|}
\hline Keterangan & Skor & Jumlah Responden & Skor Total & Presentase \\
\hline Sangat Setuju (SS) & 5 & 45 & 225 & $41 \%$ \\
\hline Setuju (S) & 4 & 62 & 248 & $56 \%$ \\
\hline Kurang Setuju (KS) & 3 & 4 & 12 & $4 \%$ \\
\hline Tidak Setuju (TS) & 2 & 0 & 0 & $0 \%$ \\
\hline Sangat Tidak Setuju (STS) & 1 & 0 & 0 & $0 \%$ \\
\hline \multicolumn{2}{|l|}{ Jumlah } & 111 & 485 & $100 \%$ \\
\hline
\end{tabular}

Dari total 111 responden sebesar $56 \%$ setuju bahwa hadir setiap hari, hal ini juga dibenarkan

Tabel 5. Pendapat Responden Mengenai Pernyataan "Dalam Bekerja Selalu Mengikuti Tata Tertib Yang Berlaku"

\begin{tabular}{|c|c|c|c|c|}
\hline Keterangan & Skor & Jumlah Responden & Skor Total & Presentase \\
\hline Sangat Setuju (SS) & 5 & 42 & 220 & $38 \%$ \\
\hline Setuju (S) & 4 & 60 & 240 & $54 \%$ \\
\hline Kurang Setuju (KS) & 3 & 9 & 27 & $8 \%$ \\
\hline Tidak Setuju (TS) & 2 & 0 & 0 & $0 \%$ \\
\hline Sangat Tidak Setuju (STS) & 1 & 0 & 0 & $0 \%$ \\
\hline \multicolumn{2}{|l|}{ Jumlah } & 111 & 485 & $100 \%$ \\
\hline
\end{tabular}

Dari total 111 responden sebesar $54 \%$ setuju bahwa setiap bekerja selalu mengikuti peraturan yang berlaku. Hal ini juga dibenarkan Tabel 6. Pendapat Responden Mengenai Pernyataan "Sistem Pendataan Kehadiran di Perusahaan Sudah Effektif"

\begin{tabular}{|c|c|c|c|c|}
\hline Keterangan & Skor & Jumlah Responden & Skor Total & Presentase \\
\hline Sangat Setuju (SS) & 5 & 29 & 245 & $26 \%$ \\
\hline Setuju (S) & 4 & 58 & 232 & $52 \%$ \\
\hline Kurang Setuju (KS) & 3 & 24 & 72 & $22 \%$ \\
\hline Tidak Setuju (TS) & 2 & 0 & 0 & $0 \%$ \\
\hline Sangat Tidak Setuju (STS) & 1 & 0 & 0 & $0 \%$ \\
\hline
\end{tabular}


Dari total 111 responden sebesar 52\% setuju bahwa sistem pendataan kehadiran di perusahaan sudah effektif. Hal ini juga dukung dengan adanya figer print sebagai alat sistem pendataan kehadiran.

Dari tiga pernyataan tentang indikator kehadiran diatas dapat disimpulkan bahwa responden lebih menekankan pada pernyataan "Bapak

Tabel 7. Pendapat Responden Mengenai Pernyataan "Peraturan Masuk Kerja \& Pulang Sudah Effektif Bagi Pegawai"

\begin{tabular}{|c|c|c|c|c|}
\hline Keterangan & Skor & Jumlah Responden & Skor Total & Presentase \\
\hline Sangat Setuju (SS) & 5 & 11 & 55 & $10 \%$ \\
\hline Setuju (S) & 4 & 81 & 324 & $73 \%$ \\
\hline Kurang Setuju (KS) & 3 & 19 & 57 & $17 \%$ \\
\hline Tidak Setuju (TS) & 2 & 0 & 0 & $0 \%$ \\
\hline Sangat Tidak Setuju (STS) & 1 & 0 & 0 & $0 \%$ \\
\hline Jumlah & 111 & 485 & $100 \%$ \\
\hline
\end{tabular}

Dari total 111 responden sebesar $73 \%$ setuju bahwa peraturan masuk kerja dan pulang kerja sudah effektif bagi karyawan. Dari hasil pengamatan langsung yang peneliti

Tabel 8. Pendapat Responden Mengenai Pernyataan "Siap Menerima Sanksi Bila Tidak Menaati Peraturan"

\begin{tabular}{|c|c|c|c|c|}
\hline Keterangan & Skor & Jumlah Responden & Skor Total & Presentase \\
\hline Sangat Setuju (SS) & 5 & 13 & 65 & $12 \%$ \\
\hline Setuju (S) & 4 & 60 & 240 & $54 \%$ \\
\hline Kurang Setuju (KS) & 3 & 38 & 114 & $34 \%$ \\
\hline Tidak Setuju (TS) & 2 & 0 & 0 & $0 \%$ \\
\hline Sangat Tidak Setuju (STS) & 1 & 0 & 0 & $0 \%$ \\
\hline \multicolumn{2}{|c|}{ Jumlah } & 111 & 485 & $100 \%$ \\
\hline
\end{tabular}

Dari total 111 responden sebesar $54 \%$ setuju bahwa siap menerima sanksi bila tidak menaati peraturan, tetapi $34 \%$ menyatakan kurang setuju hal ini dikarenakan masih ada sifat tidak menaati peraturan pada karyawan.

Dari total 111 responden sebesar $70 \%$ setuju bahwa masuk dan pulang kerja sesuai ketentuan perusahaan. Hal ini juga dibenarkan lakukan jam masuk dan pulang kerja sudah mengikuti aturan yaitu masuk jam 07.00 pulang jam 15.00 dengan istirahat $1 \mathrm{jam}$.
/ Ibu hadir setiap hari” dengan jumlah skor 485. Dari hasil pengamatan langsung yang peneliti lakukan rata rata karyawan hadir setiap harinya, jika ada karyawan yang tidak hadir maka akan mendapatkan sanksi berupa surat peringatan hingga pengurangan gaji.

2. Ketaatan Pada Peraturan Kerja 
skor total sebesar 455. Hal ini menandakan bahwa karyawan siap dan taat pada peraturan kerja khususnya dalam hal jam masuk dan pulang kerja yang ditentukan perusahaan.

Dari kedua indikator disiplin kerja dapat disimpulkan bahwa ketaatan karyawan terhadap peraturan kerja perlu ditingkatkan kembali.

Untuk mengetahui bagaimana Disiplin kerja pada PT. Sahabat Unggul International maka:

Skor Rata - rata $=\frac{\text { Jumlah Skor Responden }}{\text { Total Responden }}$

\section{KESIMPULAN DAN SARAN}

\section{A. Kesimpulan}

Disiplin Kerja pada PT. Sahabat Unggul International sudah cukup baik ini terlihat dari hasil pengolahan data tanggapan responden sebesar $47,7 \%$ yang memiliki arti cukup baik

\section{B. Saran}

Berdasarkan kesimpulan maka penulis dapat memberikan saran saran sebagai berikut:

Kedisiplinan yang sudah ada sebaiknya lebih ditingkatkan, khususnya ketaatan terhadap peraturan kerja, karena masih banyak karyawan yang belum taat terhadap peraturan kerja ini mempengaruhi tingkat kedisiplinan di perusahaan dapat menurun, oleh karena itu perlu adanya sosialisasi lebih terhadap karyawan tentang betapa pentingnya menaati peraturan kerja serta manfaat menaati peraturan kerja.

Sebaliknya keterampilan karyawan harus lebih ditingkatkan, dengan cara mengadakan pelatihan pelatihan keterampilan sesuai kebutuhan dan pekerjaan masing masing bagian, karena apabila keterampilan meningkat maka karyawan memiliki kinerja yang tinggi dan produktivitas karyawan akan meningkat sehingga karyawan dapat mencapai target yang ditetapkan perusahaan.

\section{DAFTAR PUSTAKA}

Ambar Teguh Sulistiyani \& Rosidah. (2009). Manajemen Sumber Daya Manusia. Edisi Kedua. Yogyakarta. Graha Ilmu.

Andi Supangat. (2008). Statistik Dalam Kajian Deskriptif, Inferensi Dan Paramatik. Jakarta. Kencana Preneda.

Boone, Louis E \& Kurtz, David L. (1984). Principle of Management. United States of America. Random house, Inc.

Byars, Lloyd L. (1984). Human Resource and Personnel Management. Printed In The United States of America. Irwin.

Danang Sunyoto. (2013). Metode Dan Instrument Penelitian Ekonomis Dan Bisnis. Cetakan Pertama. Jakarta. PT. Buku Seru.

Darma Tintri (2014), Pengaruh Disiplin Terhadap

Produktivitas kerja Karyawan (Study Pada PT. Food Tjipinang Jaya), Skripsi, Depok, Universitas Gunadarma.

Dede Royani (2015), Pengaruh Disiplin Terhadap Produktivitas Kerja Karyawan. (Study Pada PT. Khalista Arta Buana), Skipsi, Bogor, Universitas Pakuan. 
Dessler, Gary. (2011). Human Resource Management. Edisi 12, New Jersey, Pearson.

Edy Sutrisno. (2014). Manajemen Sumber Daya Manusia. Jakarta. Kencana Prenada Media Group.

Hasibuan, Malayu S.P. (2012). Manajemen Sumber Daya Manusia. Cetakan Keenam Belas. Bandung. PT. Remaja Rosdakarya.

I Komang Wardana. (2012). Manajemen Sumber Daya Manusia. Cetakan Pertama. Yogyakarta. Graha Ilmu.

Indah Puji Hartatik. (2014). Buku Praktis Mengembangkan SDM. Cetakan Pertama. Jakarta. Laksana.

Irham Fahmi. (2016). Manajemen Sumber Daya Manusia Teori Dan Aplikasi. Cetakan pertama. Bandung. ALFABETA.

Mondy, R. Wayne. (2008). Manajemen Sumber Daya Manusia. edisi kesepuluh. Jakarta. Erlangga.

Newman, Dian R. \& Hodgetts, Richard M. (1998). Human Resources Management. Printed in the United States of America. A Viacom Company.

Riduwan. (2007). Metode Dan Teknik Menyusun Tesis. Bandung. Alfabeta.

Siagian AO, Gunartin, K Nufus, HS Nur'aini Yusuf, A Maddinsyah, A Muchtar, (2020). A Systematic Literature Review of Education Financing Model in Indonesian School.

Siagian AO, TF Prasetyo, (2020). Strategi Pengembangan Kompetensi Usaha Kecil menengah Di Kabupaten Jombang. Jurnal Akrab Juara 5
(4),

77-85.

http://www.akrabjuara.com/ind ex.php/akrabjuara/article/view/ 1263.

Siagian, AO, (2020), "Pengaruh Dana Pihak Ketiga, Modal Bank, Jumlah Kantor Cabang, Tingkat Suku Bunga dan Jumlah Uang Beredar Terhadap Jumlah Kredit UMKM Bank BUMN", Syntax Literate; Jurnal Ilmiah Indonesia 5 (5), 1-17. DOI: http://dx.doi.org/10.36418/synt ax-literate.v5i5.1140

Siagian, AO, N Indra, (2019), Pengetahuan Akuntansi Pelaku Usaha Mikro Kecil dan Menengah (UMKM) Terhadap Laporan Keuangan, Syntax Literate; Jurnal Ilmiah Indonesia 4 (12), 17-35 vol: 4. DOI:

http://dx.doi.org/10.36418/synt ax-literate.v4i12.825

Siagian, AO, (2020), "Contribution of Inventory Accounting Systems in Improving Inventory Internal Control", Journal of Sosial Science 1 (2), 1-6.

http://jsss.co.id/index.php/jsss/ article/view/12

Siagian, AO, (2020), "Keterkaitan Individualitas Manajerial Pemasaran Dalam Menghadapi Revolusi Industri 4.0 Terutama Pada Perusahaan Manufaktur Di Jawa Tengah", Syntax Literate; Jurnal Ilmiah Indonesia 5 (10), 980-994. DOI: http://dx.doi.org/10.36418/synt ax-literate.v5i10.1669

Siagian, AO. (2008), Manajemen Sumber Daya Manusia. 
Cetakan kelima belas. Jakarta. PT. Bumi Aksara.

Simamora, Henry. (2006). Manajemen Sumber Daya Manusia. edisi ketiga. Yogyakarta. YKPN.

Singgih, Santoso. (2012). Aplikasi SPSS pada Statistik Parametrik. Jakarta. PT.Elex Media Komputindo.

Sitohang, A. (2007). Manajemen Sumber Daya Manusia. Jakarta. PT Pradanya Paramita.

Steers, Richard M. (1985). Managing, Effective Organizations. United States of America. Kent Publishing Company.
Sugiyono. 2014. Metode Penelitian Manajemen. Bandung. Alfabeta.

Sunarsi, D. (2018). Pengaruh Gaya Kepemimpinan dan Disiplin Kerja Terhadap Kinerja Karyawan Pada CV. Usaha Mandiri Jakarta. JENIUS (Jurnal Ilmiah Manajemen Sumber Daya Manusia), 1(2).

T. Hani Handoko. (2010). Manajemen Personalia Dan Sumber Daya Manusia. edisi kedua. Yogyakarta. BPFE.

Veithzal Rivai Zainal, dkk. (2015). Manajemen Sumber Daya Manusia Untuk Perusahaan. Cetakan Ketujuh. Jakarta. PT. Raja Grafindo Persada. 


\section{PANDUAN SINGKAT BAGI PENULIS JURNAL SDM JENIUS}

Panduan penulisan ini dimaksudkan untuk menyeragamkan bentuk penulisan karya ilmiah yang dikirim penulis ke redaksi Jurnal Jenius, dengan panduan penulisan sebagai berikut :

1. Naskah ditulis dalam Bahasa Indonesia dengan Abstrak Bahasa Indonesia dalam bentuk Font 12" dengan ukuran 1 Spasi dengan intisari tidak lebih dari 250 kata disertai 3 atau 4 kata kunci (keyword).

Naskah berupa Softcopy program MS Word maksimal 20 Halaman termasuk tabel dan gambar, spasi 1.

2. Sistematika penulisan disusun dengan urutan sebagai berikut :

a) Judul, nama dan alamat email penulis/peneliti tunggal.

b) Abstrak dan intisari, keyword dan kata kunci, dibuat dengan 1 kolom.

c) Batang Tubuh :

1). Pendahuluan, termasuk didalamnya intisari permasalahan

2). Perumusan Masalah

3). Tujuan Penelitian

4). Landasan teori termasuk didalamnya hipotesis dan kerangka Pemikiran

5). Metode Penelitian

6). Hasil dan Pembahasan

7). Kesimpulan

8). Daftar Pustaka

9). Seluruh isi tersebut di buat dengan 2 kolom

3. Judul ditulis dalam bentuk font Times New Roman 12" dengan huruf besar kecil dicetak tebal dan ditempatkan ditengah halaman, serta tidak lebih dari 18 kata.

4. Tulisan karya ilmiah dalam bentuk font Times New Roman 12" dengan ukuran spasi 1,0 spasi dalam bentuk kolom.

5. Gambar diberi nomor dan keterangan, sedangkan tabel diberi nomor dan keterangan diatasnya.

6. Penulisan persamaan matematika yang terdapat pada halaman naskah hendaknya menggunakan equation editor.

7. Daftar pustaka hanya memuat literature yang dirujuk dalam keterangan dan dicantumkan pada bagian akhir naskah dilakukan dengan memberikan nomor.

8. Margin atas dan kiri $4 \mathrm{~cm}$, kanan dan bawah $3 \mathrm{~cm}$, dan ukuran kertas A4.

9. Email Redaksi : jurnal.jenius@unpam.ac.id / denoksunarsi@unpam.ac.id 